\title{
“TINJAUAN TERHADAP PENGELOLAAN SAMPAH DI KOTA SAMARINDA"
}

\author{
Abdul Mukmin Rehas dan Parlindungan Pasaribu \\ mukmin@uwgm.ac.id, parlindunganpasaribu@uwgm.ac.id, \\ Dosen Fakultas Hukum Universitas Widya Gama Mahakam Samarinda
}

\begin{abstract}
ABSTRAK
Sampah selalu timbul menjadi persoalan rumit dalam masyarakat yang kurang memiliki kepekaan terhadap lingkungan. Ketidakdisiplinan mengenai kebersihan dapat menciptakan suasana yang tidak menyenangkan akibat timbunan sampah. Salah satu bentuk perilaku membuang sampah pada masyarakat adalah dengan membuang sampah di sungai. Kondisi ini menyebabkan lingkungan di sekitar tepi sungai terlihat sangat kotor akibat tumpukan sampah, lalat beterbangan, banyak tikus dan nyamuk, bahkan menyebarkan aroma yang tidak sedap. Kota Samarinda adalah salah satu kota yang sampai saat ini masih menghadapi masalah persampahan. Sehingga bagaimana peran pemerintah Kota Samarinda dalam menangani mengenai Permasalahan sampah di Kota Samarinda. Dengan menggunakan metode Yuridis Empiris, penelitian ini bertujuan untuk mengetahui peran pemerintah dalam menangani sampah di Kota Samarinda dan apa kendala yang hadapi oleh pemerintah dalam penanganan sampah tersebut. Berdasarkan hasil tersebut bahwa upaya yang dilakukan oleh pemerintah dalam rangka menangani persampahan di Kota Samarinda sudah efektif namun kurang didukung oleh Lapisan Masyarakat. Sehingga perlu adanya kesadaran bagi masyarakat untuk menjadi pelopor lingkungan yang bersih dan sehat karena manfaat lingkungan yang bersih akan dirasakan sendiri manfaatnya.
\end{abstract}

Kata kunci: Peran, upaya Pemerintah dalam Penanggulangan dan Pengelolaan Sampah di Kota Samarinda.

\begin{abstract}
Garbage always besist as a complicated problem in a society who are lacked sensitivity to the environment. Indiscipline regarding cleanliness can create an unpleasant atmosphere due to the trash heap. One form of throwing garbage in public behaviour is to throw garbage into the river. This condition causes the environment around the edges of the river looks very dirty due to the piles of garbage, flies flying around, lots of rats and mosquitoes, even spreading the scent is not pleasant. Samarinda city is one of the cities that is still facing the problem of waste. It is about how the government's role in addressing the Samarinda City garbage problem in the city of Samarinda. By using Juridical Empirically, this study aims to determine the role of government in dealing with garbage in the city of Samarinda and what constraints faced by the government in handling the waste. The result showed that the efforts made by the government in order to deal with the waste in the city of Samarinda been effective but less supported by Walks of Life. Thus the need for awareness for people to be pioneers in a clean environment and healthy for the benefits of a clean environment will be felt own benefits.
\end{abstract}

Keywords: Strategy, the Government's efforts in the Prevention and Management of Waste in Samarinda. 


\section{PENDAHULUAN}

\section{A. Latar Belakang}

Sampah selalu timbul menjadi persoalan rumit dalam masyarakat yang kurang memiliki kepekaan terhadap lingkungan. Ketidakdisiplinan mengenai kebersihan dapat menciptakan suasana yang tidak menyenangkan akibat timbunan sampah. Kondisi yang tidak menyenangkan ini akan memunculkan bau tidak sedap, lalat berterbangan, dan gangguan berbagai penyakit siap menghadang di depan mata dan peluang pencemaran lingkungan disertai penurunan kualitas estetika pun akan menjadi santapan sehari-hari bagi masyarakat (Sugito, 2008).

Bank Dunia dalam laporan yang berjudul "What a Waste: A Global Review of Solid Waste Management", mengungkapkan jumlah sampah padat di kota-kota dunia akan terus naik sebesar $70 \%$ mulai tahun ini hingga tahun 2025 , dari 1,3 miliar ton per tahun menjadi 2,2 miliar ton per tahun. Mayoritas kenaikan terjadi di kota-kota di negara berkembang. Di Indonesia, jumlah sampah padat yang diproduksi secara nasional mencapai 151.921 ton per hari. Hal itu berarti, setiap penduduk Indonesia ratarata membuang sampah padat sebesar 0,85 kg setiap hari. Data Bank Dunia juga menyebutkan, dari total sampah yang dihasilkan secara nasional, hanya $80 \%$ yang berhasil dikumpulkan. Sisa terbuang mencemari lingkungan. Volume sampah di Indonesia sekitar 1 juta meter kubik setiap hari, namun baru $42 \%$ di antaranya yang terangkut dan diolah dengan baik. Jadi, sampah yang tidak diangkut setiap harinya sekitar 348.000 meter titik atau sekitar 300.000 ton (Departemen Pekerjaan Umum, 2012).

Perilaku membuang sampah sembarangan ini, tidak mengenal tingkat pendidikan maupun status sosial. Keberadaan sampah di kehidupan seharihari tak lepas dari tangan manusia yang membuang sampah sembarangan, mereka menganggap barang yang telah dipakai tidak memiliki kegunaan lagi dan membuang dengan seenaknya sendiri. Kurang kesadaran akan pentingnya kebersihan menjadi faktor yang paling dominan, disamping itu kepekaan masyarakat terhadap lingkungan harus dipertanyakan. Mereka tidak mengetahui bahaya apa yang akan terjadi apabila tidak dapat menjaga lingkungan sekitar (Nurdin, 2004). Salah satu bentuk perilaku membuang sampah. Pada masyarakat adalah dengan membuang sampah di sungai. Kondisi ini menyebabkan lingkungan di sekitar tepi sungai terlihat sangat kotor akibat tumpukan sampah, lalat beterbangan, banyak tikus dan nyamuk, bahkan menyebarkan aroma yang tidak sedap.

Kota Samarinda adalah salah satu kota yang sampai saat ini masih menghadapi masalah persampahan. Persoalan sampah setiap tahun bertambah parah, terakhir yang menjadi masalah adalah terkait tempat pembuangan akhir (TPA) sampah kota Samarinda sudah tidak mampu menampung tumpukan sampah bahkan kondisi TPA kota Samarinda saat ini sangat memperihatinkan, karena sudah hampir sampai ke pemukiman warga. Sebagian besar masyarakat yang hidup di bantaran sungai karang mumus, Samarinda mempunyai kebiasaan membuang sampah ke sungai atau ke paritparti pembuangan air dan dari sampah sampah tersebut menimbulkan berbagai masalah antara lain lingkungan di sekitar tepi sungai terlihat sangat kotor, banyak lalat, banyak tikus dan nyamuk, bahkan menyebarkan aroma yang tidak sedap, faktor - faktor yang mempengaruhi perilaku faktor predisposisi (predisposing factor), seperti kebiasaan masyarakat, pengetahuan masyarakat tentang sampah, yang kedua adalah faktor yang memudahkan (Enabling Factor) seperti ketersediaan fasilitas tempat sampah yang disediakan dan lain sebagainya dan faktor yang memperkuat (Reinforcing Factor) seperti sikap dan perilaku petugas kesehatan.

\section{B. Permasalahan}

1. Bagaimana Bagaimanakah peran pemerintah Kota Samarinda dalam menangani permasalahan sampah di kota Samarinda? 
2. Apakah yang menjadi kendala bagi pemerintah Kota Samarinda dalam menangani permasalahan sampah di kota Samarinda

\section{Tujuan Penelitian}

1. Untuk mengetahui dan menganalisa peran Pemerintah Kota Samarinda dalam menangani permasalahan sampah di Kota Samarinda.

2. Untuk mengetahui dan menganalisa kendala bagi pemerintah Kota Samarinda dalam menangani permasalahan sampah di Kota Smarinda.

\section{METODE PENELITIAN}

\section{A. Jenis Penelitian}

Metode Penelitian yang digunakan adalah metode penelitian Yuridis Empiris yaitu metode penelitian dengan cara mengadakan penelitian langsung pada objek yang akan diteliti guna mendapatkan data yang diperlukan dan segala sesuatu yang berkaitan rumusan masalah yang dikaji atau diteliti.

\section{B. Sumber Data}

1. Data Primer

Adalah data yang diperoleh langsung dari lokasi penelitian, serta responden yang memberikan informasi kepada peneliti. Adapun cara pengumpulan data primer yaitu dengan mempelajari dan mengkaji terlabih dahulu peraturan perundang undangan terkait dengan hal yang akan diteliti yaitu tentang sampah atau persampahan.

2. Data Sekunder

Data Sekunder adalah diperoleh dari berbagai bahan pustaka seperti buku, majalah, hasil penelitian dan serta bahan-bahan yang terkait dengan permasalahan yang penulis angkat.

3. Data Tersier

adalah barupa istilah-istilah.

\section{Teknik Pengumpulan Data}

a. Studi Kepustakaan

Studi kepustakaan adalah merupakan teknik pengumpulan data dengan cara mengumpulkan data dari buku-buku yang sesuai dengan permasalahan dalam penelitian ini.

b. Studi ke Lokasi Penelitian, dimana penulis mengadakan pengamatan terhadap sasaran atau objek yang di teliti untuk menemui responden guna memperoleh data-data yang akurat dengan cara wawancara secara langsung dan Tanya jawab terhadap pihak-pihak yang terlibat secara langsung dalam objek penelitian, datadata atau informasi yang diperoleh kemudian di analisa kemudian cara yang digunakan dalam penelitian ini untuk mengumpulkan data yaitu wawancara, yang ditujukan kepada responden dan narasumber dengan menggunakan wawancara dengan cara bebas untuk membantu agar materinya tidak keluar dari metode penelitian.

c. Narasumber
1. Kepala Dinas Kebersihan dan Pertamanan Kota Samarinda
2. Warga Masyarakat (sistem sampel)

\section{D. Analisa Data}

Analisa data ini dilakukan dengan cara study dokumentasi yaitu mempelajari peraturanperaturan yang menjadi objek penelitian yang dipilih dan himpunan berdasarkan azas hukum, kaidah hukum dan ketentuan hukum positif yang mendasarinya.

\section{PEMBAHASAN}

A. A. Peran Pemerintah Kota Samarinda dalam menangani permasalahan sampah di kota Samarinda.

Pemerintah sebagai lembaga tertinggi dalam suatu Negara berwenang untuk mengatur ataupun mengendalikan apa saja yang berkaitan dengan pengelolaan lingkungan hidup di Indonesia, dan dalam Undang-undang Dasar 1945 Amandemen IIV dalam pasal 33 yang mengatur tentang sumber-sumber Negara yang menguasai hajat hidup orang banyak dikuasai oleh Negara dan digunakan sebesar-besarnya untuk kemakmuran rakyat. Dan untuk mengimplementasikan hal tersebut maka 
pemerintah melakukan hal-hal sebagai berikut :

1. mengatur dan mengembangkan kebijaksanaan dalam rangka pengelolaan lingkungan hidup

2. mengatur penyediaan, peruntukan, penggunaan, pengelolaan lingkungan hidup dan pememfaatan kembali sumber daya alam, termasuk sumber genetika.

3. mengatur perbuatan hukum dan hubungan hukum antara orang lain dan/atau subyek hukum lainya serta pembuatan hukum terhadap sumber daya alam dan sumber daya buatan, termasuk sumber daya genetika

4. mengendalikan kegiatan yang mempunyai dampak social

5. mengembangkan pendanaan bagi upaya pelestarian fungsi lingkungan hidup sesuai peraturan perundangundangan yang berlaku.

Dalam pelaksanaan pengelolaan lingkungan hidup secara nasional pemerintah bahkan mempunyai kewajiban yang dituangkan dalam undang-undang lingkungan hidup, antara lain :

1. Mewujudkan, menumbuhkan, mengembangkan dan meningkatkan kesadaran dan tanggung jawab para pengambil keputusan dalam pengelolaan lingkungan hidup.

2. Mewujudkan, menumbuhkan, mengembangkan dan meningkatkan kesadaran akan hak dan tanggung jawab masyarakat dalam pengelolaan lingkungan hidup.

3. Mewujudkan, menumbuhkan, mengembangkan dan meningkatkan kemitraan antara masyarakat, dunia usasha dan pemerintah dalam upaya pelestarian daya dukung dan daya tampung lingkungan hidup.

4. Mengembangkan dan menerapkan kebijaksanaan nasional pengelolaan lingkungan hidup yang menjamin terpeliharanya daya dukung dan daya tampung lingkungan hidup.

5. Mengembangkan dan menerapkan perangkat yang bersifat preemitif, preventif dan proaktif dalam upaya pencegahan penurunan daya dukung dan daya tampung lingkungan hidup.

6. Memamfaatkan dan mengembangkan teknologi yang akrab lingkungan hidup.

7. Menyelenggarakan penelitian dan pengembangan dibidang lingkungan hidup.

8. Menyediakan informasi lingkungan hidup dan menyebarluaskan kepada masyarakat.

9. Memberikan pengahargaan kepada orang atau lembaga yang berjasa di bidang lingkungan hidup

Sementara itu Pemerintah Kota Samarinda dalam rangka menangani permasalahan sampah dilakukan dengan beberapa hal, antara lain ;

1. Mencanangkan program 3R yakni Reduce, Reuse dan Recycle

3R merupakan program yang dimana perwujudannya sangat bergantung pada partisipasi masyarakat. Salah satu metode yang diunakan untuk mengatasi masalah sampah yakni mensosialisasikan pengelompokan sampah, namun entah mengapa cara ini tidak pernah berhasil.

Kurangnya kesadaran dan partisipasi masyarakat dirasakan menjadi persoalan utama. Masyarakat masih menyepelekan masalah sampah ini terbukti dengan masih banyaknya orang yang membuang sampah sembarangan. Akibatnya lingkungan menjadi tercemar. Masyarakat dan pemerintah harus dapat bekerja sama dalam mengatasi masalah ini, ada banyak hal yang dapat dilakukan seperti membuat aturan yang jelas Untuk mendisiplinkan masyarakat pemerintah bila perlu harus membuat peraturan yang tegas untuk setiap orang yang membuang sampah sembarangan, pemberlakuan denda mungkin akan menjadi upaya yang efektif.

2. Melakukan program Reduce artinya mengurangi 
Hal ini berarti sebisa mungkin kita harus mengurangi penggunaan barangbarang yang sulit terurai secara alami contohnya setiap kita berbelanja kita harus membawa tas belanja sendiri jangan sampai anda malah menggunakan banyak tas plastik nantinya, Reuse artinya kita harus menggunakan kembali barang - barang yang sulit terurai secara alami misal tidak langsung membuang plastik belanja. Recycle artinya mendaur ulang kembali contohnya botol-botol bekas sisa minuman bisa kita gunakan untuk bahan membuat tempat pensil atau hiasan lainnya semua hal itu dapat mengurangi jumlah sampah.

3. Membuat organisasi atau komunitas Pengelola sampah.

Saat ini pemerintah masih terbatas pada pengumpulan sampah tanpa upaya berkelanjutan, pemerintah harus membuat komunitas pengolah sampah disetiap wilayah,sehingga sampahsampah yang sudah terkumpul dalam bentuk sampah organik dan an-organik dapat ditindaklanjuti untuk menjadi sesuatu yang baru,karena sekarang ini ketika orang-orang sudah mulai mengelompokan sampah berdasarkan sifatnya ketika sampah itu di angkut oleh mobil kebersihan akhirnya malah di campur kembali.Sampah organik dapat diubah menjadi kompos, sedangkan untuk sampah anorganik kita dapat mengolahnya menjadi barang kerajinan, atau kita bisa melibatkan para penjual produk dari barang-barang tersebut untuk berpartisipasi dengan mendaur ulang bekas produk mereka untuk di daur ulang kembali.

4. Membiasakan masyarakat dengan gerakan cintai bumi

Disini dituntut partisipasi dan kesadaran masyarakat. Sebelum seseorang berniat untuk mengubah lingkungan maka orang tersebut harus memulai dengan mengubah dirinya, pengelolaan sampah secara mandiri merupakan salah satu solusi yang tepat, mulai menyediakan 2 jenis tong sampah untuk organik dan an-organik di rumah. Hal itu dapat memudahkan proses selanjutnya dari pengolahan sampah itu sendiri, disini keberhasilan program pengelolaan sampah ditentukan.

5. Mendorong semaksimal mungkin kreatifitas masyarakat.

Sebagai manusia yang dibekali akal fikiran, kita dituntut untuk bisa berkreasi, tentu dalam masalah ini pun bumi kita membutuhkan inovasiinovasi yang bisa membuat masalah sampah ini teratasi, misal dengan menciptakan alat pengubah sampah baik organik maupun anorganik menjadi suatu hal yang baru dan dapat digunakan dengan

6. Pengembangan produk dan kemasan ramah lingkungan.

7. Pengembangan teknologi, standar dan prosedur penanganan sampah
a. Penetapan kriteria dan standar minimal penentuan lokasi penanganan akhir sampah
b. Penetapan lokasi pengolahan akhir sampah
c. Luas minimal lahan untuk lokasi pengolahan akhir sampah
d. Penetapan lahan penyangga.

\section{B. B. Kendala bagi pemerintah Kota Samarinda dalam menangani permasalahan sampah di kota Samarinda}

Kendala-kendala yang dihadapi Dinas Kebersihan dan Pertamanan Kota Samarinda Dalam Upaya Penanggulangan Sampah kendala-kendala yang dihadapi dalam penanganan sampah di kota Samarinda yaitu seperti masih kurangnya jumlah TPS/kontainer di kota samarinda dan menyebabkan tingginya timbunan sampah yang ada di dalam bak kontainer serta kurangnya kesadaran masyarakat dalam mematuhi aturan waktu dan tempat dalam membuang sampah yang menyebabkan tempat pembuangan sampah selalu terlihat penuh. Padahal di area kontainer tersebut Dinas Kebersihan dan Pertamanan Kota Samarinda sudah memasang spanduk untuk selalu membuang sampah kedalam 
Kontainer . Dengan semakin meningkatnya jumlah penduduk Kota Samarinda berarti volume sampah kota pun menjadi bertambah. Jika TPS dan armada pengangkut sampah tidak seimbang dengan volume sampah yang semakin lama semakin bertambah maka akan sulit untuk menciptakan lingkungan kota yang bersih dan sehat. Dalam Peraturan Daerah Kota Samarinda Nomor 02 Tahun 2011 tentang Pengelolaan Sampah telah dijelaskan bahwa penyediaan atau pengadaan TPS, pengangkut sampah dari TPS ke TPA termasuk menyediakan gerobak sampah pada tempat tertentu dimana TPS tidak memungkinkan dibangun merupakan kewajiban Pemerintah Daerah dan menjadi tanggung jawab Dinas Kebersihan dan Pertamanan Kota samarinda dalam memberikan pelayanan kepada masyarakat khususnya dalam bidang pelayanan jasa. Hal ini mengindikasikan bahwa Dinas Kebersihan dan Pertamanan Kota Samarinda belum maksimal dalam memenuhi kewajibannya melayani masyarakat di bidang persampahan karena kebersihan merupakan tanggung jawab bersama yang mestinya disadari oleh semua pihak baik itu dari masyarakat maupun instansi yang berwenang, seperti yang tertera dalam Peraturan Daerah Kota Samarinda Nomor 02 Tahun 2011 Pasal 45 Ayat 2 menyebutkan bahwa Ketua Rukun Tetangga (RT) sebagai penanggung jawab tempat pemukiman penduduk bertanggung jawab atas ketertiban dan kebersihan lingkungan di wilayahnya. Berdasarkan peraturan tersebut dengan kata lain setiap warga wajib menjaga kebersihan lingkungannya tanpa lepas dari pantauan dan arahan dari Ketua Rukun Tetangga (RT) dan Lurah Selaku pimpinan penyelenggaraan urusan pemerintahan di wilayah kerja Kelurahan.

Jadi pada dasarnya yg menjadi kendala dalam penangan permasalahan sampah di kota samarinda yaitu :

a. Kurang disiplinnya masyarakat kota samarinda, masih banyak yang tidak mengerti dan belum sadar akan kebersihan kotanya
1) Didalam pikiran alam bawah sadar, masyarakat menganggap bahwa membuang sampah sembarangan ini bukan merupakan suatu hal yang salah dan wajar untuk dilakukan.

2) Norma dari lingkungan sekitar seperti keluarga, sekolah, masyarakat, atau bahkan tempat pekerjaan. Pengaruh lingkungan merupakan suatu faktor besar didalam munculnya suatu perilaku. Contohnya, pengaruh lingkungan seperti membuang sampah sembarangan, akan menjadi faktor besar dalam munculnya perilaku membuang sampah sembarangan.

3) Seseorang akan melakukan suatu tindakan yang dirasa mudah untuk dilakukan. Jadi, orang tidak akan membuang sampah sembarangan jika tersedianya banyak tempat sampah.

4) Tempat yang kotor dan memang sudah banyak sampahnya. Tempat yang asal mulanya terdapat banyak sampah, bisa membuat orang yakin bahwa membuang sampah sembarangan diperbolehkan ditempat itu. Jadi, warga sekitar tanpa ragu untuk membuang sampahnya di tempat itu.

b. Umur sarana dan Fasilitas yg sudah tua

c. Dan anggaran

\section{PENUTUP}

\section{A. A. Kesimpulan}

1. Upaya yang dilakukan oleh pemerintah dalam rangka menangani persampahan di kota samarinda sudah efektif, namun demikian peran pemerintah masih belum membuahkan hasil yang baik dikarenakan belum sepenuhnya upaya tersebut didukung oleh semua lapisan masyarakat karena pada dasarnya permasalahan sampah di kota samarinda ini karena masih kurangnya kesadaran masyarakat akan kebersihan kotanya.

2. Kendala penanganan sampah di kota samarinda pada dasarnya hampir sama dengan daerah lain, namun demikian yang dominan dalam kendala tersebut adalah kesadaran masyarakat terhadap 
kebersihan, pembiayaan, sarana prasarana dan penegakan hukum (sanksi)

\section{B. Saran}

\section{A. Masyarakat}

1. Mari kita menjadi pelopor lingkungan bersih dan sehat karena manfaat untuk lingkungan yang bersih kita sendiri yang merasakan manfaatnya.

2. Jangan membuang sampah sembarangan

3. Kurangi pemakaian barang atau benda yang melahirkan sampah.

\section{B. Pemerintah}

1. Perhatian terhadap sampah harus menjadi prioritas

2. Penegakan hukum terhadap perda sampah harus optimal

3. Peningkatan kesejahteraan para petugas DPK khusunya karyawan kontrak atau harian.

4. Perhatian terhadap sarana dan prasarana yang semakin tua.

\section{DAFTAR PUSTAKA}

[1] Daud Silalahi dalam Hukum Lingkungan, dalam sistim penegakan hukum lingkungan Indonesia, Alumni. 2001 hal : 10 .

[2] Adalah kesatuanruang dengan semua benda, daya, keadaan, dan mahluk hidup, termasuk manusia dan perilakunya, yang mempengaruhi kelangsungan dan kesejahteraan manusia serta mahluk hidup lain.

[3] Otto sumarwoto, 1976 di kutip dari bukunya Daud Silalahi Dalam Hukum Lingkungan, dalam sistim penegakan Hukum Lungkungan, Alumni, 2001 : hal :9

Teguh Adminto adalah Mahasiswa Fakultas Hukum dan Asisten Laboratorium Hukum Universitas Muhammadiyah Malang 